\title{
How to Do Things with Rights? On Circulation of Ideas between Great Britain and France
}

\author{
EMMANUELLE DE CHAMPS
}

Dan Edelstein's On the Spirit of Rights offers a fascinating insight into the multi-faceted "rights talk“ that made the drafting of the American Declaration of Independence and the French Declaration of the Rights of Man and of the Citizen possible at the end of the eighteenth century.

The American and French texts declared inalienable natural rights and set the conditions for their "preservation“ in political societies. Edelstein contrasts this position with two other ways of thinking about natural rights: that natural rights are „transferred“ to the sovereign (be it an individual or a body) on the creation of political society, on the one hand, and that natural rights are „abridged“ when individuals associate in civil society, on the other. ${ }^{1}$ With this reading, which lays strong emphasis on the performativity of eighteenth-century declarations, Edelstein emphasises the modernity of Enlightenment conceptions of rights and their relevance to twenty-first century politics: positive individual rights, he argues, have a long legacy in Western thought and their political force needs to be asserted and defended.

On the Spirit of Rights is a wide-ranging book which takes us through Western Europe and colonial America from the wars of religion to the Universal Declaration of Human Rights in 1948, with a specific focus on the early modern period, from 1689 to 1789. In his attempt to write a "genealogy" of human rights, Edelstein is rightly wary of identifying turning points and breaks, but he rather insists on the fluidity of discourses and on the way in which they sometimes overlap. „The history of human rights“, he writes, „may be more archaeological than seismic, with successive generations adding new layers of interpretation to older theses." (p.8). What does this nuanced way of understanding the circulation of ideas in history bring to the study of ideas of rights in the Enlightenment?

My discussion here will therefore unfold around two themes: the status of eighteenth-century declarations as performative documents and the ways in which ideas of rights circulated between the French- and the English-speaking worlds.

\section{The legal status of eighteenth-century Declarations and their critics}

Edelstein reframes eighteenth-century „rights talk“ as a debate on what kind of rights citizens keep in civil society - and not, significantly, as an opposition between those who believed that humans had natural and imprescriptible rights and those who refused such

1 For the three human rights regimes see Dan Edelstein, On the Spirit of Rights, Chicago 2019, pp. 1-6. 
a claim. This has the advantage of showing how the idea that humans had rights gradually came to win people over Britain, France and America: the question was not so much whether humans had rights or not, but which ones, and under what conditions they kept them. However, Edelstein pays relatively little attention to the legal status of these Declarations: declaring rights as natural and inalienable does not say anything about their legal value, especially, it does not turn those rights into „opposable“ rights, that is to say rights which the courts can enforce. Declarations of rights therefore have a specific status as political and legal instruments.

Edelstein's contention is that the 1776 and 1789 Declarations marked the triumph of „subjective“ rights. It is true that the two declarations were soon inserted into the constitutional apparatus of the two regimes. The US Bill of Rights shortly followed the adoption of the Constitution, whereas in France legal provisions were part and parcel of the 1789 Declaration, which itself figured (with minor variations) as a preamble to the 1791 Constitution. In so doing, revolutionaries did not limit themselves to stating broad principles or asserting individual or collective liberties, they also thought they were providing a bulwark against future encroachment by the State or by other individuals. Edelstein's book is a clear reply to those who, in the wake of Samuel Moyn's The Last Utopia, have argued that the normative value of human rights is essentially a twentieth-century invention. ${ }^{2}$ Indeed, in France, though the recognition of the constitutional validity of the 1789 declaration derived from a decision of the Conseil constitutionnel on July 16,1971, recent work by legal historians has tended to stress that in the first few years of the Revolution rights were conceived as normative and represented a driving force for positive legislation. ${ }^{3}$ It must however be pointed out that the normativity of Enlightenment declarations of rights was neither immediate nor universal - American slaves remained excluded from its remit and in France, far from being set in stone, the text of the 1789 Declaration was modified in the following decades, in a long series of constitutional upheavals. Edelstein's statement that "subjective and objective theories of natural right continued to intermingle all the way up through the Age of Revolutions" (p.13), may in fact be taken further into the nineteenth and the twentieth centuries, in that respect the Enlightenment declarations were no watershed.

The existence of subjective natural rights was, in itself, contentious point throughout the eighteenth century, and well into the nineteenth. ${ }^{4}$ Opponents claimed that the idea of natural and imprescriptible rights was as historically and conceptually false as it was

Samuel Moyn, The Last Utopia. Human Rights in History, Cambridge, MA, 2010.

See Isabelle Anselme, L'invocation de la Déclaration des droits de l'homme et de la constitution dans les débats de l'Assemblée législative (1791-1792), Paris 2013.

4 Jeremy Waldron, Nonsense upon Stilts: Bentham, Burke and Marx on the Rights of Man, London 1987; Bertrand Binoche (ed.), Critiques des droits de l'homme, Paris 1989; Justine Lacroix - Jean-Yves Pranchère, Le procès des droits de l'homme. Généalogie du scepticisme démocratique, Paris 2016. 
politically dangerous. Though more attention has been paid to the way this critique developed in the course of the nineteenth century, be it in conservative, Catholic or Marxist circles, this position was alive and well in the eighteenth century. Jeremy Bentham born in 1748, three years after Nicolas de Condorcet - expressed it forcefully in 1795 in his commentary of the version of the Declaration attached to the 1791 Constitution (which contained only minor variations from the 1789 version): „How stands the truth of things? - that there are no such things as natural rights - no such things as rights anterior to the formation of government - no such things as natural rights opposed to, in contradistinction to, legal - that the expression is merely figurative - that the moment you attempt to give it a literal meaning, it leads to error, and to that sort of error that leads to the extremity of mischief." ${ }^{\text {"5 }}$

Bentham's opinion was without appeal: „[n]atural rights is simple nonsense: natural and imprescriptible rights, rhetorical nonsense, nonsense upon stilts. "6 Moreover, to use Edelstein's categories, Bentham's attack is levelled specifically at the supporters of the preservation regime: in the same paragraph, Bentham explains, against those who claim that their natural rights have been encroached upon by the actions of government: „[t] hat [ie. a supposed right] which has no existence cannot be destroy'd: that which can not be destroy'd can not require any thing to preserve it from being destroy'd." As Philip Schofield has pointed out, this included not only the French revolutionaries, but also, closer to home, the ideas defended by Thomas Paine in Rights of Man, part I (1791). ${ }^{7}$

Bentham's critique of natural rights is often presented as the logical conclusion of his utilitarianism: setting up the greatest happiness of the greatest number as the standard of right and wrong in morals and as the criterion of legislation implies a consequentialist approach that seems to conflict with any a priori assessment of value, or statement of right. However, Bentham's utilitarianism did not exclude the appeal to external principles: namely, ,subsistence, abundance, security and equality “, ${ }^{8}$ nor to indicative declarations of principles to guide the legislator. ${ }^{9}$ For Bentham, natural and imprescriptible

5 Jeremy Bentham, Rights, Representation, and Reform: Nonsense upon Stilts and other Writings on the French Revolution, edd. Philip Schofield - Catherine Pease-Watkin - Cyprian Blamires, Oxford 2002, p. 329.

6 Iвidem, p. 330.

7 Philip Schorield, Jeremy Bentham's Nonsense Upon Stilts, Utilitas 15/1, 2003, pp. 1-19; Thomas Paine, Rights of Man, in: idem, Rights of Man, Common Sense and Other Political Writings, ed. Mark Philp, Oxford 1995, 83-178.

8 Frederick Rosen, Classical Utilitarianism from Hume to Mill, London 2003, pp. 209-255.

9 David Lieberman, Declaring Rights: Bentham and the Rights of Man, in: Ian Hunter - Richard Whatmore (ed.), Philosophy, Rights and Natural Law. Essays in Honour of Knud Haakonssen, Edinburgh 2019, pp. 306337; E. de Champs Happiness and Interests in Politics: A late Enlightenment Debate, in: Mark Philp - Georgios Varouxakis (edd.), Utility and Happiness: Essays Presented to Frederick Rosen, London 2019, pp. 306-337. 
rights, be they expressed in the words of Pufendorf, Grotius, Locke or Blackstone were fictions: they did not refer to any "real entities" and for this reason, they could not be backed with legal sanctions. As fictions natural rights did not and could not have any legal value. As Schofield and Lieberman have pointed out, this position is to be distinguished from later legal positivism, held for instance by John Austin. Bentham did not minimise the role of passions and individual representations in politics, nor did he believe that moral values were irrelevant to law or government. On the contrary, the principle of utility united the moral and the legal spheres, for it was sovereign in both. ${ }^{10}$

Bentham's rejection of natural rights as fictions is not only the product of his own specific epistemology. In political terms, his position appears to be steeped in eighteenth-century Toryism, which Bentham himself acknowledged as the political milieu he grew in, and which had a direct impact on his rejection of Whig conceptions of rights and contractual politics. ${ }^{11}$ Like Filmer in Patriarcha, Bentham dismissed together the ancient liberties of Englishmen and natural rights. Shortly before Bentham wrote A Fragment on Government, ${ }^{12}$ which came out in 1776 , Samuel Johnson had voiced similar arguments against the American colonists in a pamphlet entitled Taxation No Tyranny. An Answer to the Resolutions and Address of the American Congress: "They [= the American colonists] are ready to cooperate with all the other dominions of the king; but they will cooperate by no means which they do not like, and at no greater charge than they are willing to bear. This claim, wild as it may seem; this claim, which supposes dominion without authority, and subjects without subordination, has found among the libertines of policy, many clamorous and hardy vindicators. The laws of nature, the rights of humanity, the faith of charters, the danger of liberty, the encroachments of usurpation, have been thundered in our ears, sometimes by interested faction, and sometimes by honest stupidity. " 13

What unites this indictment with Bentham's is the accusation that rights are solely the product of caprice, that they have no foundations in history. The issue of the historicity of rights is therefore crucial to understand eighteenth-century debates on natural rights in the English-speaking world. Edelstein rightly points out the specificity of the Anglo-American tradition which combines natural rights with the historical liberties of Englishmen, with a careful analysis of Burke's position, for instance: Burke believed that

10 These points could also be made for Helvétius's utilitarianism. Helvétius is not such a clear-cut defender of rights as Edelstein claims (On the Spirit, p. 65). See E. de Champs, Happiness and Interests, pp. 23-28, 34 .

11 Jeremy Bent ham, A Comment on the Commentaries and A Fragment on Government, edd. James H. Burns and Herbert L. A. Hart, London 1977, p. 440n.

12 Jeremy Bentham, A Fragment on Government, ed. James H. Burns and Herbert L. A. Hart, Cambridge 1988.

13 Samuel Johnson, Political Writings, ed. Donald J. Greene, New Haven 1977, p. 418. 
"Anglo-American rights were grounded in the long constitutional history of the English monarchy, stretching from the Magna Carta to the Glorious Revolution. ${ }^{114}$ But dissenting opinions were in fact numerous, across the political spectrum. ${ }^{15}$

Looking back on the genealogy of anti-rights writings of the eighteenth century opens a different vista into the debate on rights. By reinserting the Filmerian tradition and its long legacy in eighteenth-century English politics in the narrative of On the Spirit of Rights, the debate on rights regimes would stand in a different light. The existence of natural and imprescriptible rights and their normative force had not yet become a shared heritage in the age of Revolutions.

\section{The circulation of ideas in the Enlightenment}

On the Spirit of Rights tells the story of how the "preservation regime" gradually emerged in the French- and English-speaking world in the seventeenth and eighteenth centuries. Stressing breaks and continuities in the transmission of this specific conception of rights involves a de-centring: unlike recent work driven by renewed interest in the natural law school in the eighteenth century, Edelstein insists that the conversation on rights was much broader and involved a larger share of civil society than those who would have been exposed to the teaching of natural law in Protestant European universities. The book is thus also an essay on the fate of ideas and on their transmission between generations, social groups and across nations and languages.

The path of ideas in complex political societies - and the picture of the Enlightenment which emerges from the book is that of a vibrant public culture - can be tortuous. For instance, Edelstein points out that the insistence of Hobbes and his followers that, though humans had natural rights in a state of nature, they forfeit them when they join political society, also invited contradiction, thus opening a forum for the opposite claims that most rights should be transferred or preserved when political society is established. Dan Edelstein's knowledge of the printed world of the Enlightenment in the Frenchand English-speaking worlds is encyclopaedic, as is his familiarity with the historiography of the period across the fields of history and philosophy. In moving seamlessly between different levels of analysis, he remains aware of the gap between broad conclusions and minute case-studies (though it must be said that these nuances, present in the endnotes or within individual paragraphs, are often missing from introductory and conclusive sections).

14 Edmund Burke, Reflections on the Revolution in France, in: idem, Revolutionary Writings, ed. lan Hampsher-Monk, Cambridge 2014, p. 59, 17, 34. See D. Edelstein, On the Spirit, p. 172.

15 In his 1958 essay „The Norman Yoke“, while retracing how arguments from English liberty and from rights were interwoven in British radical thought from the Civil War to the Chartists, Christopher Hill charted the development of tory thought which constantly opposed these joint claims. Christopher Hill, The Norman Yoke, in: idem, Puritanism and Revolution [1958], New York 1997, pp. 46-111. 
In the central chapter entitled „From liberalism to liberty“. Edelstein makes the point that "the country that issued the Declaration of the Rights of Man and of the Citizen showed little indication, during the first fifty years of the eighteenth century, that it cared much about natural rights or believed that the purpose of society was to conserve „the natural and imprescriptible rights of man“, (p. 61). It then argues that was a revival of rights-talk in the 1750s and 1760s, driven by the group of economists around François Quesnay known as the Physiocrats, which in turn nurtured the soil on which revolutionary natural rights flourished. This narrative is offered as an alternative to the better-known case for the diffusion of natural law ideas. To make this point, Edelstein relies on a series of connected case studies, each drawing on distinct but complementary methodological tools: from word frequency graphs to chart the fortune of phrases such as "natural rights" and "natural law" in a corpus of French texts published between 1700 and 1790 (p. 62-63, 68) to close readings of articles from Diderot's and D'Alembert's Encyclopédie, followed by a study of the reception of Locke's political thought in France (p. 68-71), then of how English works in which the „preservation regime“ of rights was stated circulated in France. In the second section of this chapter, he analyses the Physiocrats' political thought and the central place they made for claims that citizens retained their rights (especially to property) in civil society, thus creating the conditions for the revival of the preservation regime of rights in the 1780s. Charting the circulation of such a polysemic concept over one century, especially when it involves international circulations is an ambitious attempt, and Dan Edelstein is right to multiply methodological angles. It is however likely that almost each of the specific claims on which his narrative hinges will be debated by specialists. The rest of this discussion briefly flags two such areas.

„Where is Locke's Second Treatise of Government in the French Enlightenment?", Dan Edelstein asks. Provocatively, his answer is that in France „Enlightenment rights talk cannot be described as 'Lockean'“ (p. 69-71). This move parallels the much less recent side-lining of Locke's Second Treatise in eighteenth-century English-speaking political culture. It rests on the well-documented idea that Locke's fame in Enlightenment France was mostly derived from the Essay concerning Human understanding and from the Reasonableness of Christianity, which circulated much more widely than the Two Treatises. In his study, Dan Edelstein weaves together qualitative and quantitative evidence, but his close reading rests mostly on the Encyclopédie and on Diderot (p.70). One can wonder whether the picture would be different if one were to look more closely at other types of sources (such as periodicals and newspapers, for which no exhaustive database exist for the period, a point he rightly makes) and other political traditions, such as classical republicanism were to be examined. Ultimately, one may wonder whether the relative fading of Locke into the background isn't liked to Edelstein's attempt to write a history of rights which deliberately moves away from Rousseau. The 1780-89 Genevan 
edition of the Euvres complètes de Rousseau, searchable through FRANTEXT, returns 48 mentions of Locke. ${ }^{16}$ Rousseau was a critical reader of Locke, but a reader nonetheless, and the publicity he gave to the Englishman's ideas no doubt played a part in the surge of interest of the revolutionaries for the Englishman's political thought. Indeed, the 1794 French edition of the Traité du gouvernement civil flagged the topicality of Locke's ideas in the 1790s: „Le gouvernement despotique avait empêché que l'on connût beaucoup son Traité du Gouvernement Civil et on ne peut choisir un moment plus favorable pour en publier une Édition correcte et plus belle que toutes celles qui ont paru, que celui où l'on sent en France la nécessité urgente d'un bon Gouvernement. "“7

Second, picking up on Keith Baker's insight, ${ }^{18}$ a number of recent studies have proved the vivaciousness of French republicanism in the age of Enlightenment and have mapped out its intellectual and political relations with English-language republicanism. ${ }^{19}$ This is also a channel through which a more radical idea of rights gradually gained ground in France, and one which is surprisingly absent from the book. In this scholarship, close attention has been paid to the circulation of republican ideas in print through translations and in the periodical press.

Within these republican networks, the figure of the younger comte de Mirabeau (Honoré Gabriel Riqueti de Mirabeau) stands out. ${ }^{20}$ Mirabeau is regularly quoted in On the Spirit of Rights as one of the main proponents of the "preservation regime“ of rights in the revolutionary period. He was also, as Dan Edelstein reminds us, the son of a prominent Physiocrat, the marquis de Mirabeau, nicknamed "l'ami des hommes" and close to Mercier and Quesnay. Mirabeau fils thus appears in the book as a key link between the physiocratic discourse of rights (focused as it was on property) and revolutionary claims of a natural and imprescriptible right to liberty (p. 81). But Mirabeau's long political career and his extensive writings and journalism which span the 1770s and 1780 s cannot be limited to the transmission of physiocratic ideas. His reading and

16 See https://www.rousseauonline.ch, accessed on 24 May 2020.

17 Traité du gouvernement civil, par M. Locke, Paris 1794.

18 Keith Baker, Transformations of classical Republicanism in Eighteenth-Century France, The Journal of Modern History 73/1, 2001, pp. 32-53.

19 A good introduction is provided by Le républicanisme anglais dans la France des Lumières et de la Révolution, in: François Quastana - Pierre Serna (edd.), La Révolution française - cahiers de l'Institut d'histoire de la Révolution française 5, 2013, pp. 1-8. For studies focusing on the circulation of books and pamphlets, see Rachel Hammersley, The English Republican Tradition and Eighteenth-Century France: Between the Ancients and the Moderns, Manchester 2010; Raymonde Monnier, Traduction, transmission et Révolution: Enjeux rhétoriques de la traduction des textes de la conception républicaine de la liberté autour de 1789, Annales Historiques de la Révolution Française 364/4, 2011, pp. 29-50.

20 François Quastana, La pensée politique de Mirabeau (1771-1789): „Républicanisme classique“ et régénération de la monarchie, Aix-en-Provence 2007. 
writing spanned several intellectual, political and religious traditions which he drew on to construct an increasingly scathing indictment of absolute monarchy. These traditions included Protestant natural law, the economic laissez-faire of the Physiocrats, Locke.... A truly cosmopolitan figure, Mirabeau supported Genevan exiles, translated works from the English and German (or had them translated) and moved in diplomatic circles. In Mirabeau's case influence was always cumulative, and never exclusive. Mirabeau's prolific writings and his journalism played a key role in building up political unrest against the French monarchy. Indeed, claims of natural rights figured prominently among the intellectual, political and rhetorical tools he employed and he gained an increasing audience in the years preceding 1789 , but in the book, the diversity of influences and the cross-fertilisation between different ideologies falls victim to the prominent role given to the Physiocrats.

All in all, Dan Edelstein's On the Spirit of Rights provides a challenging narrative on the development of discourses about rights in Enlightenment Europe and America. In a relatively short format (223 pages of text plus 78 of endnotes) it develops an original and persuasive thesis. It keeps alive the debate on rights in the Enlightenment and invites further studies. 
Emmanuelle de Champs

How to Do Things with Rights?

On the Circulation of Ideas between Great Britain and France

Abstract

Based on Dan Edelstein's fascinating theses, Emmanuelle de Champs explores the status of eighteenth-century declarations as performative documents and the ways in which ideas of rights circulated between the French and the English-speaking worlds. She agrees that the impulses of the Declaration of 1789 were elaborated during the Revolution and even during the $19^{\text {th }}$ century, but recalls that their normative status in their own age was questioned. Emmanuelle de Champs explores critiques which grew from the Tory heritage of England, where she includes Jeremy Bentham, Edmund Burke or Samuel Johnson. In the critical responses to the French Declaration, Bentham basically treated rights as fictious entities which should not be backed by any legal sanctions. These thinkers questioned what Dan Edelstein calls the 'preservation regime of human rights'. Emmanuelle de Champs approvingly follows Edelstein's attempt to show how the idea was disseminated in France before 1789, but asks whether it would not be better to follow not only the Encyclopédie and Diderot but also the periodical press. She suggests that this was also the channel through which British republican ideas were disseminated in France.

KEY WORDS:

human rights; French revolution; Jeremy Bentham; Edmund Burke; legal theory 